\title{
Spoilage and Squatting: A Lockean Argument
}

\author{
Eloise Harding ${ }^{1}$ (D) \\ Published online: 20 November 2019 \\ (c) The Author(s) 2019
}

\begin{abstract}
John Locke is generally seen as an unequivocal defender of private property. However, taken normatively, certain aspects of his argument leave room for interesting loopholes with relevance to some of today's social and political crises. This paper focuses largely on the spoilage proviso-in which Locke warns against appropriating more than one can make use of - and its possible application to abandoned buildings and the potential for legitimate productive use to be made of them by people other than the legal owner. Using two case studies in which squatters have actively reversed the dereliction of abandoned buildings, this article aims to build a defence of certain types of squatting based on the limitations Locke has placed on the appropriation and (by some readings) the retention of property.
\end{abstract}

Keywords Locke $\cdot$ Property $\cdot$ Spoilage proviso $\cdot$ Squatting $\cdot$ Housing

\section{Introduction}

The legal context of this article is the 2012 criminalisation of squatting of unoccupied residential buildings in the UK. Here the official definition of squatting is 'when someone deliberately enters property without permission and lives there, or intends to live there' (gov.uk undated). Since September 2012, the offence has carried a possible sentence of ' 6 months in prison, a $£ 5000$ fine or both' (gov.uk undated). The relevance of Lockean political thought is drawn from the rhetoric used by proponents of the revised squatting laws: the 'hardworking' property owner is a favoured trope of politicians such as the then housing minister Grant Shapps (BBC News 2012). The sanctity of private property is emphasised, as is the labour of those who own property: both topics which raise the spectre of Locke's theory of property acquisition through adding one's labour to some communal raw material.

Eloise Harding

m.e.harding@soton.ac.uk

1 Politics and International Relations, University of Southampton, Murray Building (58),

Highfield Campus, Southampton SO17 1BJ, UK 
The key thesis of this article can be seen as somewhat counterintuitive: the 2012 squatting laws could more easily be perceived as meeting Locke's approval, given his insistence on the right to defend one's property from expropriation. However, elements of his thought make the case less clear-cut. In particular, the spoilage proviso contains the kernel for a defence of certain types of squatting: here, Locke argues that 'As much as anyone can make use of to any advantage of life before it spoils: so much he may by his labour fix a property in. Whatever is beyond this, is more than his share, and belongs to others' (Locke 2nd Treatise, section 31). This point need not be stretched far to encompass buildings left to become derelict. The arguments made here are more plausible when grounded in a humanitarian reading of Locke's overall theory consistent with those put forward by James Tully or Richard Ashcraft. This is discussed in more depth in the following section. This paper draws from two examples chosen due to the ease of obtaining data: ${ }^{1}$ while both occupations took place in the same city within a few years, the issue is far wider than I can cover in a single article.

Before proceeding, it is worth outlining why Locke's arguments are of interest in a discussion of squatting. The main reason is that if even a heavily bounded defence of squatting can be drawn from the arguments of a political thinker largely concerned with defending the rights of property owners, this indicates both a strong line of defence for the types of squatting covered and some interesting ambiguities in the original theory. If this is the case, there are significant implications for the current culture around property ownership. As such, this analysis has potential to be of both current and historical interest.

The argument advanced here hinges on an interpretation of Locke's theory grounded in the centrality of the preservation of human life and wellbeing and in the constraints he places on the morally acceptable use of resources. If we interpret his overall argument for private property in this context—as, for example, the best way to ensure that entire populations have the resources they need to surviverather than as a source of social segregation and relentless accumulation on the part of the few, then occasional exceptions to the general rules start to appear feasible. Such a case has some precedent, particularly in the work of Richard Ashcraft, who holds that Locke saw each individual as part of a 'natural community' (Ashcraft 1987 , p. 100) whose collective interests were central to Locke's analysis of political society. This is of course far from universally accepted, ${ }^{2}$ but my aim is to build a case for this reading throughout the paper. This approach raises its own questions, in particular regarding Locke's focus on God as the motivation for preserving both humanity and natural resources. How, then, do his arguments translate into today's more secular environment? Approximately as well, I suggest, as his politics map

\footnotetext{
${ }^{1}$ Both occupations took place within a short walk from my then home, and I visited and participated in events at both. Ethics prevent me from drawing directly from those experiences in academic work: however, they have provided me with a greater depth of understanding of how these and similar occupations function.

${ }^{2}$ Placing me in esteemed company such as Shrader-Frechette (1993), Nine (2010), and potentially Tully (1993).
} 
onto those of the squatters' and landless peasants' movements: imperfectly, but with scope for constructive discussion and interpretation in the uncertain spaces. Certainly the historical Locke saw religious motivations as underpinning every part of his argument: however, this does not render the conceptual Locke ${ }^{3}$ impotent if the religious element is de-centred. His concern for (and conception of) human wellbeing can be read as valid in itself and, more importantly, as a motivation in itself for urging decent behaviour in the allocation of resources. Furthermore, his arguments regarding natural resources can, in the ways that matter, continue to stand if we apply a more neutral placeholder concept in the role of 'creator': the simplest and most neutral being the natural processes and ecosystems which sustain our lives. In this context, the spoilage proviso continues to make sense as a principle for regulating the use of resources.

\section{A Lockean Defence of Squatting}

I will begin by offering the central argument for why Locke's theories can be applied to a bounded defence of squatting. This may generate controversy, and the main objections are dealt with in the final section. The elements making it a bounded defence are discussed at the end of this section.

To advance a Lockean defence of squatting, it is necessary to give the spoilage proviso serious consideration as a continuing limitation on property acquisition and ownership. It is generally accepted that the spoilage proviso only refers to property consistently disused or wilfully destroyed by its owner: it does not, therefore, place restrictions on how much property an individual can obtain, but merely on what she can subsequently do with it. She may acquire the rights to any number of buildings, provided she can put them to some form of use before they become derelict: those she cannot or will not make sensible use of, she is welcome to pass on to another individual in exchange for money. In the present day, her initial acquisition is bounded by the amount of money at her disposal: this presents less of a limit in an urban environment than those set by her capacity for physical labour. Any of these scenarios are acceptable from a Lockean perspective. What would not be acceptable, however, would be for our intrepid entrepreneur to retain possession and exclusive (dis)use rights over buildings she cannot or will not make use of, while they become derelict and dangerous, since 'nothing was made by God for man to spoil or destroy' (Locke 2nd Treatise, section 31). As such, her unique claim over the derelict buildings ends when it becomes apparent that this is happening: her property holdings have gone beyond what she can 'make use of to any advantage of life before it spoils' (Locke 2nd Treatise, section 31). Property which is beyond one's share, Locke makes clear, 'belongs to others' (Locke 2nd Treatise, section 31). We can of course quibble about the nature of the claim these 'others' may have, and whether this amounts to outright transfer of ownership or merely to a (longer or shorter term)

\footnotetext{
3 A distinction borrowed from Shrader-Frechette (1993).
} 
use right, but the removal of one's exclusive rights to abandoned surplus property is a key tenet of Locke's theory.

This exception to a theory which can otherwise be construed as a defence of private property has two central elements. Firstly, Locke objects to what he perceives as 'wastage' of the resources provided for humanity by our alleged creator. Secondly, his overall argument can be interpreted as being grounded, not in relentless acquisition of property for its own sake, but in concern for the survival and wellbeing of humanity as a whole: in other words, in the purpose Locke ascribes to the aforementioned creator when providing resources. Property rights, Tully argues, are accompanied by duties: each person 'has a property for the sake of preserving himself and others' (Tully 1993, p. 132), and as such 'once his own preservation is secured, any further use for enjoyment is conditional on the preservation of others' (Tully 1993, p. 132). The purpose of appropriation is in the first instance for each individual to obtain her own means of survival: at this stage, there is very little ${ }^{4}$ discrimination regarding which individual can achieve this. The acquisition of land by cultivation may be less open to all comers: however, here Locke explicitly states that such cultivation will increase the quantity of resources which can be made available to the population as a whole. The labour inherent in appropriation 'does not lessen, but increase the common stock of mankind: for the provisions serving to the support of human life, produced by one acre of inclosed and cultivated land, are (to speak much within compass) ten times more than those which are yielded by an acre of land of an equal richness lying waste in common' (Locke 2nd Treatise, section 37). This emphasis on the improved stock of common resources supports Tully's reading of Locke as concerned not with a privileged few but rather with humanity as a whole. ${ }^{5}$ Indeed, those who have an excess are, as per the First Treatise, required to give charity to those whose appropriative endeavours have not yielded success. Locke's many references to providing humankind with the means of survival can thus be taken literally as easily as they can be taken to refer to the specific subset of humankind who have successfully appropriated land or other resources. The spoilage proviso is where these concerns converge.

I should also indicate a minor role for Locke's other apparent proviso, regarding leaving 'enough and as good' (Locke 2nd Treatise, multiple sections) for others. I have assigned it a lesser role here purely due to the ambiguity over whether Locke intended it as a lasting normative constraint on the legitimate accumulation of property or merely as an empirical point regarding the initial condition. However, since the contexts in which squatting generally takes place tend not to be ones where there is 'enough and as good' left, it warrants some discussion.

The proviso (Locke 2nd Treatise, section 33) could almost certainly be used in favour of the argument advanced here. Squatters' movements tend to grow when

\footnotetext{
${ }^{4}$ I hesitate to say 'none', since the capacity to perform basic tasks such as picking apples is undoubtedly a restriction. This is problematic (albeit symptomatic of the time he was writing) with regards to questions of disability, particularly when further labour is required. It is, however, outwith the scope of this paper to investigate the question further.

${ }^{5}$ This is not to overlook elements we might now consider racist, but rather to frame them as hypocrisies in the light of his wider argument.
} 
there is categorically not enough housing left for others, let alone as good, making the ownership of neglected buildings fit the description of 'prejudice to any other man' (Locke 2nd Treatise, section 33). This decade is no exception. Shapps's crackdown on squatting happened in the light of a 14\% increase in homelessness and a $20 \%$ rise in rough sleepers in 2011. However, when putting forth this proviso Locke refers explicitly to the appropriation of land 'by improving it' (Locke 2nd Treatise, section 33) - in effect framing the principle to exclude land (or other property) which has already fallen foul of the spoilage proviso. It should also be noted that the meaning of Locke's declarations on 'enough and as good' is somewhat ambiguous - is he, for example, making an empirical point regarding what he perceives as a near-unlimited supply of natural resources available for the taking at the time of writing, or a normative moral one regarding the eventual limit to appropriation? Since I cannot conclusively demonstrate the latter point, I am loath to rely on it overly in shaping my argument, although the proviso has a role to play: this role will now be discussed.

Given the respective levels of sustained discussion in the Second Treatise, it is likely that Locke attaches less importance to the enough and as good proviso than he does to spoilage-based restrictions. This has often been taken as evidence that it forms a less powerful or even largely insignificant constraint on the accumulation of property. Waldron (1988), for example, reads it as providing just grounds for accumulation if there is indeed enough and as good left for others, while not intrinsically ruling out just accumulation if there is not. Layman levels a challenge at this interpretation, pointing out that 'Locke's text makes it very hard to deny that there is some kind of serious moral problem with distributions that leave some people badly off while others thrive' (2018, p. 156). Layman advances the following Lockean conception of a just distribution of resources: it 'must both accord with the aim of natural law and result from a series of rightful transfers in order to be morally acceptable' (Layman 2018, p. 156). By this reckoning, a distribution which 'fails to secure preservation for all' (Layman 2018, p. 156) is morally objectionable even if it originates in a series of initially rightful appropriations and transfers. ${ }^{6}$ Individuals' rights, then, should not compromise the overall goal of preservation of the human species. Nine takes a similar approach in her Lockean case for territorial rights for ecological refugees, in which she argues that 'the existing territorial rights of states should change because of the change in circumstances' (Nine 2010, p. 366). Because the existing distribution of land has been rendered unfair through the destruction of some groups' original territory by climate change, the distribution must be altered to keep up with events. This redistribution, she argues, does not need to be strictly egalitarian: however, the ecological refugees nonetheless have some claim over sovereign territory, even where this is under the jurisdiction of another state.

Nine constructs a normative case for territorial redistribution based on Lockean principles, particularly the 'enough and as good' proviso, consistent with Layman's

\footnotetext{
${ }^{6}$ A related argument is made by Beade (2019), who argues that the element of blame should be removed from squatting in circumstances where governments have not ensured that basic needs such as shelter are met.
} 
claim that a distribution of resources is only acceptable in the terms put forward by Locke if it in some sense helps to secure preservation for all. It is debateable whether extensive or indeed any property rights for all must be enshrined in this distribution, but it must ensure that nobody is blocked from obtaining the means of self-preservation: and, I would add, that nobody's possession of wasted surplus property should contribute to the morally dubious distribution of resources. By this reckoning, the 'enough and as good' proviso can be seen to offer some form of constraint on reckless acquisition, even after the initial period of appropriation and the superseding of appropriation through labour by trading with money. We cannot, of course, know Locke's intention in writing this statement, and the case that he intended it as an empirical point about the situation in which initial appropriations took place cannot be ruled out. It can, however, be feasibly extrapolated from his overall concern with the preservation of humankind that he would not have condemned such a constraint in cases where the extant distribution of resources could be construed as a threat to survival.

With specific regard to squatting, then, the following defence can be drawn with relative safety from Locke's arguments. Firstly, that it is not justifiable under the spoilage proviso, even once mitigated by the advent of money, to own a property portfolio beyond what can be, if not consistently in use, then at least maintained to some basic level. Secondly, that given Locke's overall concern with the preservation of humankind, the 'enough and as good' proviso can be brought to bear as a further argument constraining the justifiability of allowing buildings to become derelict while in one's possession in a time where housing shortages are a major problem. And, finally, that the continuing derelict condition of an owned but abandoned building justifies the loss of exclusive rights to it.

With that in mind, we must now look at the possible rights of occupation or reappropriation conferred on others firstly by the abandonment of a building by its named owner and secondly by the subsequent labour of the occupiers in reversing the derelict state of the building and putting it to some form of constructive use. A case can be made for outright transfer of ownership, since Locke has suggested at various points in his argument that an individual's otherwise wasted surplus belongs to others. In the First Treatise, he argues that God has given the needier members of the population 'a right to the surplusage' (Locke First Treatise, section 42) of the goods of others; when outlining the spoilage proviso, meanwhile, he is clear that anything left to spoil 'belongs to others' (Locke 2nd Treatise, section 31). However, Locke also puts forth an extended defence against arbitrary (or by some readings any) expropriation of what an individual has claimed through the application of her labour. Hence, a consistently Lockean defence of squatting must stay in the safer waters of use rights and a duty to share these as an alternative to abandonment of one's land or buildings.

As we saw earlier, it is a feature of property rights that they in general contain an element of exclusiveness: Kate's ownership of a building can usually be taken to encompass her right to choose who accesses this building and makes use of the facilities. Here, the relevance of the original owner's labour and her claim to the resulting property as its fruit can also not be ignored. Although the existence of money clouds the issue somewhat, we should assume for the sake of argument 
that Locke's ideas on legitimate appropriation still apply, and that part of the claim brought about by this appropriation pertains to having exclusive use of the property. Reeve suggests that 'To be secure in this enjoyment of an individualised incentive a person must be able to exclude others from the reward which he receives' (Reeve 1986, p. 119). Again, however, this can be framed in terms of an incentive to labour and to continually make use of the property and improve it where necessary. Hence, the initial appropriation and any use made of the property would have been legitimate, but this does not in itself overrule the spoilage proviso. However, taken in conjunction with the provisos discussed above, Kate's ownership of the building can be construed as a 'service tenure' (Ryan 1984, p. 35), which implies that claims to private property (and specifically to its exclusive use) depend largely on the owners making productive use of it. As such, her exclusive use right to the building lapses when it becomes derelict through lack of attention on her part, even if her overall ownership claim does not. At this point, our focus must move to squatters Sue and Rose, who have established that Kate appears to have no intention of either using the building constructively or selling it, and believe that they can make it an asset to the community once they and their comrades have put in the required light repairs and heavy cleaning. The overall distribution of resources in society means that community spaces and housing are both in short supply. In these circumstances, an argument can be made on Lockean grounds for Sue and Rose applying their labour to the building in order to turn it back into a functional space and a more pleasant neighbour for the surrounding area. Kate would, by this reckoning, be justified in asking them to vacate were she to find her own use for the building. She may not, however, legitimately evict them merely to allow the building to continue to decay.

I have previously alluded to making a bounded defence of squatting grounded in Locke's theory of property. It is now time to discuss these bounds in greater depth. The defence of squatting which can be drawn from Locke's arguments is not universal and necessarily covers different ground from the bulk of arguments made by squatters in their own defence. The distinctions between pro-squatting arguments will be discussed shortly. Much potential exists for confusion, due partly to the variety of conceptions of 'squatting' but largely to the popular discourse on the subject and its tendency to conflate very different situations. In the interests of clarity we must examine the debate around the specifics of property ownership, particularly regarding its duration. Alan Ryan observes that while rights over abandoned property may not be indefinite, nonetheless 'we should not wish to lose our beds the moment we rose from them or our clothes the moment we took them off' (Ryan 1984, p. 34). The parallel with regard to squatting is the media trope of the family whose home is squatted when left empty short-term. The pressure group Squatters' Action for Secure Homes argue that 'There has not been a single corroborated case of anyone's actual home (where they were actually living at the time) being squatted in over 40 years' (SQUASH 2013). Rather, 'When you scratch beneath the surface of each story, you find that the truth is misrepresented, and usually the property owner's actual home is elsewhere' (SQUASH 2013). However, even this scenario may not be fully justified by Lockean arguments if the building is merely empty as opposed to abandoned: after all, it is feasible that the owner may yet intend to use the property 'to any advantage of life before it spoils' (Locke 2nd Treatise, section 31). 
While he may suggest that such properties be used charitably, it would be difficult to derive outright condemnation of the owners for not doing so from either the First or Second Treatise. There are more questions pertaining to the legitimacy of ownership than I could fully engage with here without significant digressions, but which need to be addressed. I have for the most part accepted Ryan's conception of the claim on land as a service tenure, as discussed above. This definition categorically excludes the occupation of somebody's home, or of an operational business premises. Vacating a home for a holiday or a factory for a weekend does not open it up as a potential squat by this reckoning, since the need is for 'continuing rather than continuous use' (Ryan 1984, p. 34). I would, for instance, hope not to lose a coffee cup left on my desk should I take a short break from writing this article. However, were I to abandon the same cup by my workplace's sink, I would not expect to retain possession indefinitely, particularly if such items were in short supply around the building. Likewise, if the owners of a building have a plan to make productive use of it in the future, and are maintaining it in the meantime so that it does not become a hazard to those around it, then their possession is by this reckoning secure. As such, the defence offered here is not valid for cases which fit the media stereotype: rather, it can be taken to apply to the occupation of abandoned and neglected buildings by squatters who have made noticeable improvements.

Squatting is not a monolithic concept, so I will narrow the field to establish which varieties of squatting can be defended with the argument given here. The typology offered by Pruijt (2013) proposes five largely distinct categories. These are deprivation-based squatting, squatting as an alternative housing strategy, entrepreneurial squatting, conservational squatting and political squatting. While these categories are not strictly mutually exclusive, the discussion here is largely confined to deprivation-based and entrepreneurial squatting. Deprivation-based squatting can be broadly conceived as a form of direct action against large-scale homelessness, in the sense that it provides housing while also making a point about the existence of both a problem and a viable solution. In Lockean terms it engages with 'enough, and as good left' (Locke 2nd Treatise, section 33) as much as with the spoilage proviso. Entrepreneurial squatting is somewhat removed from conventional meanings of the term 'entrepreneur'. In general terms it refers to turning squatted space into, for example, community facilities or educational spaces. The squats discussed in this article existed in Nottingham between approximately 2005 and 2011. ASBO-short for 'A Simple Building Occupation'-occupied a number of adjoining boardedup council houses consistently for several years during the early part of that time period. The council initially tried to evict the squatters, but eventually allowed them to stay. The squat eventually broke down due to internal political tensions beyond the scope of this article. JB Spray was a disused factory in an adjacent neighbourhood, which was occupied for several shorter periods punctuated by evictions and re-occupations. Both buildings were in some disrepair, requiring much mending and cleaning to make them habitable. The ASBO squatters had to contend with an overgrown garden that had become a base for drug dealing and prostitution, both industries having left behind evidence among the weeds. Initial tasks at JB Spray included removing dead pigeons and pigeon droppings, and blocking the entry points used by the pigeons and other wildlife. Both forms of squatting, and the examples used here, 
are consistent with the 'common good' interpretation of Locke which underpins this article.

Finally, it should be noted that the owner of the squatted building loses not the ownership of their property, but merely its exclusive use for the duration of the occupation. This is a very different scenario from those Locke argues against: his overarching concern is by many interpretations to protect property owners from having their land, dwelling or other means of subsistence arbitrarily confiscated by the sovereign. No squatter with any sense ${ }^{7}$ will stake a claim to own the occupied building: nonetheless, they add their labour to it and derive benefit from the result of that labour in the form of a roof over their head. It should also be noted that the owner of the building also derives some benefit from the labour of the occupiers, since most productive use requires (for example) cleanliness and functional plumbing. While insistence on an outright transfer of ownership might not be justified on Lockean grounds, even by the 'service tenure' interpretation, a requirement that exclusive use-rights be surrendered in order to keep the building in some form of productive use could be. ${ }^{8}$

\section{ASBO and JB Spray}

This section gives the empirical details of the two case studies and grounds them in Lockean arguments regarding spoilage and the preservation of human life and wellbeing. The purpose here is to demonstrate how the abandonment of buildings to a derelict condition is liable to contravene Locke's general principles to a greater extent than the unauthorised use and occupation of the buildings concerned.

The following is from Indymedia posting detailing the initial occupation of the buildings that became ASBO:

10 days ago, these folks squatted a building that had been empty for seven years. Over the last week, they had a tidy of the rubbish out of the garden, shooo'd away the drug abusers out of the yard, painted out the graffiti, got rid of the needles found around and about. (Tash [alan lodge] 2005)

These squatters also un-boarded the windows, mended numerous holes and generally went about making the buildings safe for human habitation: the first steps in turning it from a drug den into a community resource. Initial projects included free Internet, a bike repair collective and a 'free shop' which accepted donations and gave them away. There was also a 'People's Kitchen' on Saturday evenings, serving healthy meals (usually based around food salvaged from skips) at low cost. Later in proceedings ASBO added an element of deprivation-based squatting to the largely entrepreneurial project, providing housing for refugees who had trouble finding it elsewhere. The overall ethos here was in tune with resisting spoilage: both the food

\footnotetext{
7 Those without such sense are outwith the purview of this paper.

8 The typology of ownership rights and lease rights suggested by Wells (2018) may provide a starting point for investigating precisely which rights are and are not lost in such scenarios.
} 
supplies and the building were abandoned by others as surplus to immediate needs. In today's era this concept tends to be framed in terms of the wastefulness of consumer society. While Locke would find little wider political common ground with the squatters, this is one area where their arguments largely coincide. He argues, after all, that legitimate property is limited to 'As much as anyone can make use of to any advantage of life before it spoils' (Locke 2nd Treatise, section 31), while, as previously mentioned, anything beyond this share should be ceded to others. There was also an element of community service in the squatters' projects, consistent with readings of Locke's arguments which posit him as favouring the preservation of all humankind.

ASBO eventually became what is known as a legitimate squat, accepted by the council as an official dwelling. Part of the rationale here was the improvements the squatters had made to the site, and in particular the positive response from the neighbours. Again, it is possible to make a somewhat cautious case for using Locke's arguments to endorse the council's decision. In his view, God 'gave [the world] to the use of the industrious and rational, (and labour was to be his title to it) not to the fancy or covetousness of the quarrelsome and contentious' (Locke 2nd Treatise, section 34). Opinions in the Arboretum area were mixed about squatting in general, and some feedback was certainly negative, but overall local residents preferred ASBO's new incarnation to its previous one. ASBO did not therefore end in eviction but in a breakdown of relations between residents. A year after the eventual breakdown, the building and grounds were back in their previous condition.

The JB Spray squat in nearby Radford had a less straightforward timeline. Contributing factors included a greater level of transience among the core group of squatters and more harassment from other sections of the local population. The most significant factor, however, was the lack of co-operation from the building's owner and the property management company he had hired. The council planning department summarised the situation thus: 'J B Spray \& Co., Russell Street II Private 3 Vacant. Factory and chimney stack at risk. Owner unwilling to sell or to find economic use for building, despite availability of grant-aid' (Fellow Squatter 2006). In this instance, then, the owner had the opportunity to access help in order to reprise productive use of his building, and in particular to repair the damage that was making it a danger to neighbours and passers-by: contravening, in a very real way, their 'right to their preservation' (Locke 2nd Treatise, section 25).

The tasks facing the initial group of squatters included heavy cleaning, patching up holes, checking the structural safety of parts of the building and unblocking the toilets to create a semblance of usable sanitation. Hygiene was a major concern, with upper floors in particular full of dead birds and bird droppings, and there were many other signs of neglect and disrepair. In practice JB Spray was largely an entrepreneurial squat, in the sense used by Pruijt. Projects included free film showings and community art displays, as well as some charity events. Initial plans addressed the homelessness problem and demonstrated intentions to branch out into deprivation-based squatting: however, this was made difficult by the insecurity of the occupation. In the longest gap between occupations, the point has been made that the building deteriorated significantly. An Indymedia posting made during an attempt to evict a later occupation predicted: 'When they are evicted... the building will return 
to being an empty eyesore with more bits continuing to fall off, and those currently housed there... become homeless. Squatting is not a crime, but the owners right to just let it rot... should be' (Tash [alan lodge] 2010).

Locke may well agree on the latter point, particularly where there is clearly not 'enough and as good' left. While many squatters disagree with private property as a concept, concurrence with this view is not a strictly necessary prerequisite for objecting to the acquisition of surplus perishable property. Here, if we accept Locke's overall argument, concerns arise regarding the role of money in rendering spoilage a non-issue. This will be discussed in more depth in the final section: for now the brief answer is that the existence of money does to an extent override the spoilage proviso, but only in the sense that money in itself does not spoil. Whatever moral implications might arise from hoarding it do not feature in this debate-as opposed to the problems that arise from long-disused buildings.

At this stage, it would be useful to acknowledge the original basis of Locke's argument, the initial appropriation of property through the application of one's labour. Unfortunately, he does not provide clear guidance as to how (or whether) potential reappropriators should proceed in cases of obvious abandonment or spoilage. However, his insistence throughout chapter 5 of the Second Treatise on the addition of value through labour indicates that the work carried out by the squatters at both ASBO and JB Spray are potentially consistent with his theory. Each squatter, after all, owns the 'labour of his [or her] body, and the work of his [or her] hands' (Locke 2nd Treatise, section 27), and has mixed this with a hitherto abandoned building in order to bring it back to a safe and productive condition. We must, however, bear in mind that the question of reappropriation will always be a thorny one in Lockean terms, for there are many cases where mixing your labour with an object that is in name the property of another can be rejected out of hand: hence, the spoilage criterion must already be established for this element of the squatters' actions to be justified. It is the abandonment of the buildings concerned which distinguishes the actions of these squatters from those of, say, an individual who digs up the contents of their neighbour's flourishing vegetable patch and lays claim to both carrots and land as a result.

It should also be noted that both projects were, at least by virtue of their intentions, consistent with the Ashcraftian reading of Locke which underpins this article. While Ashcraft's community-spirited interpretation of Locke is controversial, it can feasibly be applied to cases of squatting and land reclamation when the aim ${ }^{9}$ is to contribute in some way to the common good. While this does not rule out acceptance of squatting for personal gain, it does add an extra dimension for assessing each case.

\footnotetext{
${ }^{9}$ The question of whether these intentions are realised successfully is outside the remit of this article.
} 


\section{Countering the Objections, and Some Outstanding Concerns}

As with any argument relying on an interpretation of a historical text, mine is far from immune to objections grounded in other readings of Locke's Two Treatises. I will now provide counter-arguments to the most significant ones I can foresee.

The most basic objection to the spoilage-based element of my argument relates to the invention of money, and its role in (by some interpretations) superseding the provisos which initially restricted the appropriation of resources for private use. Answering this concern requires investigation of the mechanics of the apparent override. Money, Locke states, is "some lasting thing that men might keep without spoiling' (Locke 2nd Treatise, section 47), which can be taken 'in exchange for the truly useful, but perishable supports of life' (Locke 2nd Treatise, section 47) should the population consent to using it thus. Hence, an individual whose orchard yields more apples than she can eat can sell the surplus and buy more food at a later date with the proceeds. If she cannot pick subsequent apples herself, she can buy the labour of others who do not possess their own orchards. What she does with any profit is largely her business, since precious metals 'may be hoarded up without injury to anyone' (Locke 2nd Treatise, section 50). Nothing in this discussion, however, indicates that she would be entitled to leave the apples to rot on the tree year after year, or would have legitimate grounds for complaint if her neighbours were (after a decent interval) to make use of the apples. A doubter may ask at this point whether it is more acceptable to buy a surplus of apples, with the transfer of money mitigating the inconvenience to others of the apples being removed from circulation, and leave these to rot. This analogy runs closer to the situation of many squatted buildings, and may in a market economy be a more pertinent concern: however, nothing in Locke's argument establishes that this is the case. He does not, for example, discuss how the advent of non-perishable currency might supersede the initial motivating factor of preserving the human species. Rather, the ability to trade one's surplus for a currency that will not rot appears to suggest opportunities to increase the common stock of mankind' (Locke 2nd Treatise, section 37), through the potential to produce to the greatest extent of one's labour (or ability to buy the labour of others) without spoilage. ${ }^{10}$ His argument here does not intrinsically create a case for allowing appropriation beyond one's capacity or willingness to labour, when this is to the detriment of others.

The second objection is drawn from the work of critics such as Macpherson, who argue that the sum total of Locke's remit is to protect the rights of property owners from incursion by non-property owners. Macpherson in particular locates Locke's motives in the legitimation of emerging social relations in which property ownership was construed as the key to political participation and citizenship rights. It was an accepted tenet of Locke's political era that 'human beings of a labouring class were a commodity of which riches and dominion might be derived' (Macpherson 1962, p. 229); and as such 'the labouring class was rightly subject to but without

\footnotetext{
${ }^{10}$ Neither, of course, does he provide a solution for the wellbeing of those who cannot obtain sufficient quantities of the metal concerned, beyond the charity requirement in the First Treatise.
} 
full membership in the state'(Macpherson 1962, p. 229). If Locke does not explicitly argue for this point of view, it is because he 'did not have to argue these points' (Macpherson 1962, p. 229); he 'could assume that his readers would take them for granted, as he did' (Macpherson 1962, p. 229). Squatters, by this reckoning, would not be recognised as political actors in a Lockean theory, since they are nonproperty-holders who fail to fulfil their anointed role. Furthermore, since Locke's intention is to cement the lower position such people occupy in society, he must by definition allow no scope for social divisions to be breached, and in particular for property rights to be openly disrespected.

However, Macpherson's conclusions can be seen as peremptory in the light of the premises on which he bases them. It is, for example, a significant conceptual jump ${ }^{11}$ from 'not a political participant' to 'a commodity' or even 'a nonentity'. It is a bigger conceptual jump from Locke's demarcations of political society to the necessarily callous treatment of those outside such demarcations. Locke places children outside the category of political actors, yet does not argue for harsher discipline than was usual in his day. Furthermore, in addition to his pronouncements regarding spoilage and the need to leave enough and as good for others, Locke's interpretation of his alleged creator's wishes indicate views opposite to the callousness perceived by Macpherson. In his words, 'God the Lord and Father of all, has given no one of his children such a property, in his peculiar portion of the things of this world, but that he has given his needy brother a right to the surplusage of his goods; so that it cannot justly be denied him, when his pressing wants call for it' (Locke First Treatise, section 42). With regards to squatting, buildings such as JB Spray can be considered 'surplusage' and hence subject to the 'pressing wants' of others for shelter. Certainly, Locke's emphasis on the preservation of humankind and our natural right to this and 'such other things, as nature affords for their subsistence' (Locke First Treatise, section 42), provides as much evidence for interpretations such as Cara Nine's as other aspects of his theory do for Macpherson's. Nine's argument, that a 'basic and natural reading of the Lockean proviso, then, is that when the holding or acquisition of property rights unnecessarily threatens human life, we should change something about property dispositions to avoid the unnecessary death caused by these property dispositions' (Nine 2010, p. 361), holds some water in the overall context of Locke's case for the initial existence of private property. By this reckoning, while individuals who do not own property may be excluded from some aspects of citizenship in the society Locke envisions, the undercurrent of callousness read into his arguments by Macpherson cannot be taken as gospel. On the specific question of squatting, then, the need of some for shelter could be said to override the initial claim of others over their (in the circumstances) excessive property portfolio.

The third objection relates to the possible benefits to the building owner of retaining the building in its empty, derelict condition: the case that keeping it thus qualifies as 'the greatest convenience of life they were capable to draw from it' (Locke 2nd Treatise, section 34). These benefits may be somewhat dubious, and all but invisible

${ }^{11}$ Albeit one which reflects attitudes in many capitalist societies today; however, twenty-first century labour practices were not in Locke's purview. 
to the rest of us, but they may nonetheless warrant protection from being unilaterally overridden by squatters. Possibilities here include a wish to save on demolition costs by allowing the ravages of time to do the work of clearing the land for productive use, or indeed abiding by planning laws which make the slower method of reclaiming the site the more feasible one, ${ }^{12}$ maintaining a property portfolio against which to secure loans; or possibly conducting a scientific experiment into entropy. ${ }^{13} \mathrm{By}$ some interpretations (such as Olivecrona 1974), we can derive from Locke's argument that any benefit a property owner derives from ownership justifies the continued retention of the property and the sole use thereof, regardless of the various provisos. However, how far does this fit with the spirit of his overall theory of property? Ryan reports that Locke does not provide a clear account of 'which ways of enjoying we should prefer' (Ryan 1984, p. 37): however, it would take a very generous interpretation of '[making] use of [the earth] to the best advantage of life, and convenience' (Locke 2nd Treatise, section 26) to incorporate the wishes of the individual who 'enjoys watching apples decay, or playing bowls with them' (Ryan 1984, p. 37). While Locke does not offer a clear dividing line between the 'industrious and rational' and those exhibiting 'fancy and covetousness' (Locke 2nd Treatise, section 34), many of the 'benefits' derived from leaving one's buildings to become derelict can at the very least be considered to occupy a blurred boundary between the two categories.

In light of the above, we should also consider whose 'greatest convenience of life' Locke considers to be at stake in this debate. His Treatises provide no evidence that he is restricting this 'convenience' to a select few: rather, he refers [as, subsequently, does Nozick (1974)] to the benefits to the whole of humankind when advancing his case for appropriation by labour and the claims it subsequently confers.

The fourth objection relates to whether a building can be placed in the same category as an apple or even a piece of land for the purpose of applying the spoilage proviso. This potentially controversial point is subject to surprisingly little engagement in the relevant literature. Certainly, although Locke refers to obtaining shelter through appropriation and labour, the question of whether that shelter can 'spoil' with disuse did not exercise him as much as the prospect of the same thing happening to land or food supplies. However, centuries later when we can see the effects of time on an abandoned building, I would argue that the principle can and should be extended.

A sixth objection can be found in cases which initially appear to satisfy some of the criteria suggested here, but may nonetheless give rise to different moral intuitions. Of particular interest here is the affluent squatter, for whom neither necessity nor scarcity are serious concerns, but who nonetheless applies labour to an abandoned building to make it fit for her own purposes, satisfying the purely spoilagebased criterion. Indeed, the elements of the squatters' movement discussed here coexist more-or-less peacefully with what can be categorised as 'lifestylist' squatters. I do not intend to engage with the more general rights and wrongs of these

12 Thanks to Stephven Shukiatis for this suggestion.

${ }^{13}$ I thank Katharine Gilchrist for this suggestion. 
forms of squatting, but rather will focus on the Lockean angle. With this in mind, let us imagine two hypothetical squatters, Sandi and Hari, occupying similar abandoned buildings. Sandi and her housemates represent an idealised version of the squatters in my case studies. Some of the residents are genuinely lacking alternative accommodation or the resources to obtain it (meaning there is not 'enough and as good' for people in their position), and everybody is engaged in making the site useful to the wider community. Hari and her housemates are acting purely for their own benefit: each of them could easily afford to rent a far better property, but they prefer not to for (usually) political reasons. ${ }^{14}$ In cases of initial appropriation, Hari's reasons would be sufficient: however, reappropriation requires a stronger justification. Each household applies similar levels of labour to improving the building they occupy, in line with the spoilage proviso. What, then, is the difference? In Lockean terms, a basic response might be that Sandi's household represents the 'industrious and rational' (Locke 2nd Treatise, section 34) advocated by Locke and Hari's the 'fancy or covetousness' (Locke 2nd Treatise, section 34) he criticises. This is not, however, a satisfying answer in itself, and can be easily contested using a different interpretation of 'industriousness'. To fully illustrate the distinction, then, we must draw again from the reading of Locke which emphasises his concern for the wellbeing of all humankind, even in the initial appropriation of resources for individual use. By this reckoning, Sandi's squat would be covered by the defence advanced in this article, and Hari's would not, less because of the genuine need on the part of some of the former and more because the latter contribute little to the wider community. At most, such a defence could be levelled if Hari's household are better neighbours to the rest of the street than, say, a crack den or a dangerously derelict building, implying that their labour has had a positive impact on the community. However, the defence would still be stronger in the case of Sandi's household, since their impact ranges from reducing pressure on council housing through to providing resources to the wider community. The distinction, then, is not intrinsic to the financial or class status of the squatters, but rather hinges on the contribution being made to society as a whole, as per the interpretation of Locke as concerned with the improved condition of all humankind. Such cases indicate that while the spoilage proviso alone offers some defence of squatting, it must be reinforced by other principles in order for the defence to be a robust one.

The final objection can be drawn from Locke's wider case against arbitrary expropriation. Locke appears to be mainly concerned with arbitrary expropriation by the state or monarch: however, his argument covers a greater range of scenarios, of which squatting could be considered one. Waldron (1988) situates the Lockean right to immunity against expropriation in the wider 'natural' right to property. This immunity takes the form of a 'claim-right' (Waldron 1988, p. 27): in Waldron's example the owner of a car holds this right 'against everyone else (her neighbours, her friends, the local car thief, everyone in the community) that they should not use her Porsche without her permission' (Waldron 1988, p. 27). Hence, the owner of a derelict building can be said to have a claim-right against others that they should

14 Anyone wishing to explore these reasons should look at the work of the Crimethinc collective. 
not occupy her building against her wishes, regardless of whether this is beneficial to the building's condition. Olivecrona goes further, arguing that in labouring on an object the Lockean appropriator 'identifies with it and in a sense makes it part of himself' (cited Waldron 1988, p. 195). Hence, 'to allow anyone else to use the object without his consent would be to allow them to use a part of his personality' (Olivecrona 1974 cited Waldron 1988, p. 195).

By this reckoning, then, squatters may be accused of trespassing on not just the building owner's economic interests, but also her personal integrity. Again, however, the condition of buildings such as JB Spray provides a possible counterpoint to such arguments. How far can an individual be said to identify with a building which she has allowed to become a safety hazard, and how consistent can it be with Locke's overall message of improvement through labour?

So far, the question of the intrinsic wrong of expropriation has been left open. Whatever the nature of the claim the original appropriator has over her property, we must assume that it cannot be contravened lightly with Locke's approval. However, it is worth noting that the key trespassers on this claim may not be those whose entitlement to the surplus is discussed above. Rather, his concerns stem directly from his arguments regarding good leadership. The task of a ruler encompasses 'the regulation and preserving of property', which is done explicitly 'only for the public good' (Locke 2nd Treatise, section 3). Humans enter political society in order to protect their property (in the wider sense encompassing life and liberty), not to put it at further risk. To this end, 'the supreme power cannot take from any man any part of his property without his own consent' (Locke 2nd Treatise, section 138). By this reckoning Locke appears motivated by fear not of a landless peasants' uprising but rather of excessive taxation and other attempts by governing bodies to lay claim to the fruits of citizens' labour. Thus, Tully argues that Locke's main concern was the protection of property rights 'against attacks from absolute monarchs or "degenerative" representative bodies' (Tully 1993, p. 77). Tully, an exponent of the view that Locke aimed to protect rather than oppress the ordinary person, interprets the previously cited claims regarding leadership thus: 'To say that government ought to preserve property is to claim that they, and especially the king, cannot infringe the citizens' life, liberty or possessions without their, or the majority's, consent' (Tully 1993, p. 120). While Tully's interpretations of Locke's arguments have faced controversy, and at times he strays further from the concept of private property than Locke's claims realistically allow, this element of his argument is consistent with those made by Locke.

This cannot in itself be taken as an indication that Locke would not have criticised the practice of squatting. While his key concern was expropriation by the state or monarch, he could hardly be said to defend arbitrary expropriation or reappropriation more generally. However, in cases such as ASBO and JB Spray mitigating factors exist which prevent a Lockean defence being severely undermined. Firstly, it should be noted again that there is no legal loss of ownership in such cases: all that is lost is the practical claim on being the sole (non-)user of a disused building. To return to my earlier example of a coffee cup, the situation is akin to the cup's owner leaving it available while she goes on sabbatical then needing to reclaim it (be this with greater or lesser difficulty) from an otherwise cupless colleague on her return; and furthermore reclaiming a cup which 
has been washed by the borrower after the owner has left it in a suitable condition to grow mould. Of course the borrower may still be criticised for using the cup without its owner's permission, but she would have a ready defence in the long-term neglect and health hazard potential of the temporarily abandoned cup. In the squatting case, then, my argument can be tempered by the admission that Locke may wish squatters to hand the building back readily were it to be put to some use by its owner in the aftermath. However, this does not diminish the justification of the initial squatting action, in the event that the building has been genuinely disused for a sufficient stretch of time.

Alongside the objections, there are some wider issues which need to be addressed in light of the arguments made here. For example, interpreting Locke's provisos as I have done here might have implications beyond squatting, since the absence of 'enough and as good' applies to resources other than housing. There are as many problems with abandoned land as with abandoned buildings, and the Lockean case made here apply equally in that instance (see for example Harding 2019). Food is a particularly pertinent issue with regards to both spoilage and 'enough and as good': France's prohibition on supermarkets destroying unsold food and requirement that it must instead be donated to food banks (see for example Chrisafis 2016) certainly comes within the purview of the argument made here. Similar arguments may potentially be applied to the trend for 'throwaway' fashion, although this would raise greater complexities than it is possible to engage with fully here, particularly since surplus is currently frequently sent to places where it does more harm than good. The principles discussed here could certainly be used to advocate more general sharing of surplus through means such as clothes swaps and lending 'libraries of stuff', and the reduction of waste through ventures such as repair cafes.

Questions can also be raised about the implications for the negligent owner of a building who, on seeing it squatted, decides to adopt the principles outlined here and allow the new residents to stay until she has a clearer use for it. Would she, for example, be liable if one of her unanticipated tenants were to sustain an injury due to the derelict condition of their temporary home? This question goes outside the scope of a strictly Lockean argument, since he does not discuss harms that individuals may incur from the use of another's property. However, it is feasible to suggest that the squatters in such cases possess some duty of self-preservation when investigating and proceeding to occupy a building in a derelict condition, and must exercise due care during the subsequent entry and occupation. This is not to excuse the owner from all liability relating to the condition of her building. In particular, with reference to the dangers posed by the JB Spray factory discussed in this article, she should certainly be held responsible for any injury to the wider public or damage to neighbouring property caused by the building's dereliction.

\section{Conclusion}

This paper set out to present and defend a defence of certain types of squatting drawing from the arguments put forth by John Locke. While this can be seen as counterintuitive given Locke's overall defence of private property, it is largely consistent with the aspects of his argument relating to spoilage and surplus. The construction 
of this argument presents a challenge to those who read Locke as favourable to extremes of inequality and lacking in decency to those who do not own property. The defence of squatting which can be derived from Locke's arguments is a somewhat bounded one: the occupied building must have been left to decay and must not be being put to a sensible use by its owner; the squatters must improve rather than degrading the condition of the building; attempts should be made where possible to use the space to mitigate homelessness or other social problems; and the building should be returned to its owner in the event that she wishes to put it to some productive use. Within these boundaries, however, such a defence is entirely consistent with Locke's overall theory of property.

Acknowledgements I would like to thank the residents of ASBO and JB Spray, the many colleagues and students at the Universities of Stirling and Southampton who have commented on versions of this paper during its long genesis, the reviewers for Res Publica for their contributions to the robustness of the eventual argument, and several reviewers at other journals who rejected earlier versions with useful and constructive comments.

Open Access This article is distributed under the terms of the Creative Commons Attribution 4.0 International License (http://creativecommons.org/licenses/by/4.0/), which permits unrestricted use, distribution, and reproduction in any medium, provided you give appropriate credit to the original author(s) and the source, provide a link to the Creative Commons license, and indicate if changes were made.

\section{References}

Ashcraft, Richard. 1987. Locke's Two Treatises of Government. Allen and Unwin.

BBC News. 2012. Squatting Set to Become a Criminal Offence. http://www.bbc.co.uk/news/uk-politics19429936. Accessed 02 Aug 2016.

Beade, Gustavo. 2019. Who Can Blame Whom? Moral Standing to Blame and Punish Deprived Citizens. Criminal Law, Philosophy 13: 271-281. https://doi.org/10.1007/s11572-018-9471-z.

Chrisafis, Angelique. 2016. French Law Forbids Food Waste by Supermarkets. https://www.theguardia n.com/world/2016/feb/04/french-law-forbids-food-waste-by-supermarkets. Accessed 24 Apr 2019.

Fellow Squatter. 2006. JB Spray Building Occupied/Evicted/Re-occupied. https://www.indymedia.org.uk/ en/2006/07/344121.html. Accessed 10 Aug 2016.

gov.uk. undated. Overview of Squatting Law. https://www.gov.uk/squatting-law/overview. Accessed 24 Aug 2015.

Harding, Eloise. 2019. Grow Heathrow: A Lockean Analysis. Critical Review of International Social and Political Philosophy. https://doi.org/10.1080/13698230.2019.1565565.

Layman, Daniel M. 2018. Sufficiency and Freedom in Locke's Theory of Property. European Journal of Political Theory 17 (2): 152-173.

Locke, John. 1998. Two Treatises of Government. London: Everyman.

Macpherson, Crawford Brough. 1962. The Political Theory of Possessive Individualism: Hobbes to Locke. Oxford: Oxford University Press.

Nine, Cara. 2010. Ecological Refugees, States Borders, and the Lockean Proviso. Journal of Applied Philosophy 27 (4): 359-375.

Nozick, Robert. 1974. Anarchy, State, and Utopia. Oxford: Basil Blackwell.

Olivecrona, Karl. 1974. Appropriation in the State of Nature: Locke on the Origin of Property. Journal of the History of Ideas 35 (2): 211-230.

Pruijt, Hans. 2013. Squatting in Europe. In Squatting in Europe: Radical Spaces, Urban Struggles, ed. Squatting Europe Kollective, 17-60. Minor Compositions: Wivenhoe.

Reeve, Andrew. 1986. Property. London: Macmillan.

Ryan, Alan. 1984. Property and Political Theory. Oxford: Basil Blackwell. 
Shrader-Frechette, Kristin. 1993. Locke and Limits on Land Ownership. Journal of the History of Ideas 54 (2): 201-219.

Squatters' Action for Secure Homes (SQUASH). 2013. FAQ. http://www.squashcampaign.org/resources/ frequently-asked-questions/. Accessed 27 Apr 19.

Tash [alan lodge]. 2005. Nottingham Squatting Project, the Tidy-Up: The Pictures. https://indymedia.org. uk/en/2005/08/321800.html. Accessed 08 Aug 2016.

Tash [alan lodge]. 2010. Spray Squat Prepare for Possible Eviction... Again. https://www.indymedia.org. uk/en/2010/08/456510.html. Accessed 10 Aug 2016.

Tully, James. 1993. An Approach to Political Philosophy: Locke in Contexts. Cambridge: Cambridge University Press.

Waldron, Jeremy. 1988. The Right to Private Property. Oxford: Clarendon.

Wells, Katy. 2018. The Right to Housing. Political Studies. https://doi.org/10.1177/0032321718769009.

Publisher's Note Springer Nature remains neutral with regard to jurisdictional claims in published maps and institutional affiliations. 